\title{
Physiological potential of peanut seeds submitted to drying and storage ${ }^{1}$
}

\author{
Karina Laís Leite Sarath², André Luís Duarte Goneli², Cesar Pedro Hartmann \\ Filho $^{2 *}$, Tathiana Elisa Masetto ${ }^{2}$, Guilherme Cardoso Oba ${ }^{2}$
}

\begin{abstract}
This study was performed to evaluate the immediate and latent effects of drying air temperature on the physiological potential of peanuts (Arachis hypogaea L.). The fruits were harvested at the physiological maturity stage, with $36 \pm 2 \%$ water content (w.b.), and dried at temperatures of 40, 50, 60 and $70{ }^{\circ} \mathrm{C}$, until $7 \pm 1 \%$ (w.b.). Thereafter, the fruits were stored in an environment with non-controlled temperature and relative humidity for 150 days, and the water content, germination and vigor of seeds were immediately determined, as well as at every 30 days thereafter, through the first count, and the tetrazolium test, accelerated aging test, cold test with soil and electrical conductivity. According to the results, it was found that the physiological potential of peanut seeds is inversely related to the drying temperature and the storage time, due to the fact that the germination and vigor are reduced as both factors increase. The air temperature of $40{ }^{\circ} \mathrm{C}$ may be recommended for the drying of peanut seeds, and even associated with the storage time of 150 days under uncontrolled conditions.
\end{abstract}

Index terms: Arachis hypogaea L., germination of seeds, vigor, post-harvest.

\section{Potencial fisiológico de sementes de amendoim submetidas à secagem e ao armazenamento}

\begin{abstract}
RESUMO - O presente trabalho foi conduzido com o objetivo de avaliar os efeitos, imediato e latente, de diferentes temperaturas do ar de secagem sobre o potencial fisiológico de sementes de amendoim (Arachis hypogaea L.). Os frutos foram colhidos no estádio de maturidade fisiológica, com aproximadamente $36 \pm 2 \%$ de teor de água (b.u.), e submetidos à secagem nas temperaturas de $40,50,60$ e $70{ }^{\circ} \mathrm{C}$, até atingirem $7 \pm 1 \%$ (b.u.). Posteriormente, esses foram armazenados em ambiente com temperatura e umidade relativa não controladas por 150 dias, sendo imediatamente e a cada 30 dias subsequentes determinado o teor de água, a germinação e o vigor das sementes por meio da primeira contagem e dos testes de tetrazólio, envelhecimento acelerado, frio com solo e condutividade elétrica. De acordo com os resultados obtidos, verificou-se que o potencial fisiológico das sementes de amendoim diminui com o aumento da temperatura de secagem e com o tempo de armazenamento, posto a germinação e o vigor das sementes serem diminutos conforme o incremento de ambos os fatores. A temperatura do ar de $40{ }^{\circ} \mathrm{C}$ pode ser recomendada para a secagem de sementes de amemdoim, sendo associada ao período de armazenamento de 150 dias em condições não controladas.
\end{abstract}

Termos para indexação: Arachis hypogaea L., germinação de sementes, vigor, pós-colheita.

\section{Introduction}

Peanuts (Arachis hypogaea L.) are among the main oilseeds planted in Brazil and worldwide currently, mainly since this culture counts on a broad adaptability and short cycle, and also because it is an important vegetable protein and oil source (Nakagawa and Rosolem, 2011; Santos et al., 2012). However, it was due to its characterization as an alternate fuel source that its importance increased regarding agribusiness, thus, increasing the speculations related to the intensification of its culture (Araujo et al., 2014; Vasconcelos et al., 2015).

Within this context, the importance of some aspects within the peanut producing sector became more prominent, such as the ones related to the post-harvest stages and the respective quality control(Barbosa et al., 2014). Therefore, some care with operations such as drying and storage, commonly conducted within a highly technology-oriented seed production system, became even more necessary and relevant, considering the establishment of the crop and, consequently, the fact that the desired production increments depend directly on the quality

${ }^{1}$ Submitted on 06/07/2016. Accepted for publication on 07/11/2016.

${ }^{2}$ Universidade Federal da Grande Dourados, Faculdade de Ciências Agrárias, Caixa Postal 533, 79804-970 - Dourados, MS, Brasil.

*Corresponding author< cphartmann21@hotmail.com> 
of the seed (Peske et al., 2012). As reported by Fernandes and Rosolem (1999) and by Krzyzanowski et al. (2006), the drying method directly influences the quality of the peanut seeds and the productivity of the culture, considering that the promotion of vigorous plants and, consequently, the adequate development of the crop depend directly on this operation.

Drying is characterized for reducing the biological activity of the seeds, therefore, hampering possible chemical and physical changes that may occur on the product during storage (Ullmann et al., 2015). In turn, the aim of the latter is to stock the product in a safe manner up to its commercialization (Smaniotto et al., 2014). However, when conducted without the due care, both operations may lead to a reduction on the quality of the seeds; drying may immediately harm the harvested material, and storage may aggravate the damages caused by drying, affecting specially the storage potential of the product (Afonso Júnior and Corrêa, 2000; Ullmann et al., 2010; Menezes et al., 2012a; Menezes et al., 2012b; Oliva et al., 2012; Mutegi et al., 2013; Faria et al., 2014).

Based on these considerations, the aim of this study was to evaluate the physiological potential of peanut seeds submitted to different drying temperatures associated to different storage periods.

\section{Material and Methods}

This study was conducted at the Laboratory of Physical Properties of Agricultural Products of Plant Sciences Department of the Federal University of Grande Dourados, located in the municipality of Dourados, MS, Brazil.

The peanut fruits from the IAC - 505 variety were manually harvest during the physiological maturity stage, according to the determination by Nakagawa and Rosolem (2011), with water content of approximately $36 \pm 2 \%$ (b.u.). Then, they were submitted to the drying process, which occurred on an oven with air-circulation and air renewal, using constant temperatures of 40, 50, 60 and $70{ }^{\circ} \mathrm{C}$, during the period of $42,36,18$ and 11 hours for each temperature, respectively.

During drying, the fruits were arranged on perforated metallic trays, and at every hour, they were turned over in order to avoid the moisture accumulation on any part of the mass. The trays were periodically weighted, and the final water content of $7 \pm 1 \%$ (b.u.) was determined by the gravimetric method.

After drying, the peanut fruits were stored according to the drying treatment on permeable polyethylene bags. The closed bags were kept on an environment with non-controlled temperature and relative humidity for a period of 150 days, and the physiological quality of the seeds was immediately evaluated after drying at every 30 days subsequently. In order to follow the temperature and the relative humidity of the air on the location during the storage period, two thermohygrometers installed close to the packages were used.

The water content of the peanut fruits and seeds right after harvesting and during storage were determined according to the gravimetric method, using a regulated oven at $105 \pm 3{ }^{\circ} \mathrm{C}$, for 24 hours, on both replications (Brasil, 2009).

In order to evaluate the quality of the seeds, the germination, first count, tetrazolium, accelerated aging, cold test with soil and electrical conductivity tests were used. Before assembling each test, except for the accelerated aging and electrical conductivity tests, the seeds were removed from the fruits and went through pre-conditioning at $25{ }^{\circ} \mathrm{C}$ for 24 hours, where they remained on suspended stainless steel screens inside gerbox-type plastic boxes, with $40 \mathrm{~mL}$ of distilled water on the bottom. Then, the seeds were disinfected on a hypochlorite solution at $2 \%$ for five minutes, and then they were rinsed with distilled water.

The germination and first count tests were jointly conducted, using four subsamples with 50 seeds, for each treatment, distributed on paper rolls moistened with distilled water, at a volume equivalent to three times the mass of the dry paper, and maintained at $25{ }^{\circ} \mathrm{C}$ on a Mangelsdorf germinator. The evaluations were conducted on the fifth and the tenth day after the installation of the test, calculating, on the fifth day, the percentage of normal seedlings for the first counting, and, on tenth day, the percentage of normal and abnormal seedlings and dead seeds, according to the criteria established on the Rules for Seed Testing (Brasil, 2009).

For the tetrazolium test, four replications with 50 seeds for each drying treatment were used, and they were firstly preconditioned for 18 hours at $25{ }^{\circ} \mathrm{C}$ on a paper towel with a water volume equivalent to 3 times the mass of the dry paper, and, then, they were kept submerged on a 2,3,5- triphenyl tetrazolium chlorite solution at $1 \%$, for 24 hours, at $30^{\circ} \mathrm{C}$, for coloration. The results were expressed as the percentage of viable seeds (Moore, 1985).

The accelerated aging test was conducted according to the methodology described by Marcos-Filho (1999), with 300 seeds for each treatment, distributed on a single and uniform layer on a stainless steel screen, which was then suspended inside a gerbox-type plastic box, containing $40 \mathrm{~mL}$ of distilled water on the bottom. The boxes, then closed, remained on a B.O.D. chamber with controlled temperature of $40{ }^{\circ} \mathrm{C}$ for 48 hours. After this period, the water content of the seeds was determined, and the germination test was conducted (Brasil, 2009), and the percentage of normal seedlings was calculated on the fifth day after assembling the test.

For the cold test with soil, conducted according to 
the methodology described by Barros et al. (1999), four subsamples with 50 seeds were used for each treatment. They were sown on plastic boxes containing a mix of sand and soil (1:1) and moistened with distilled water, aiming at keeping $60 \%$ of the water retention capacity of the substrate. The boxes were kept on a B.O.D. chamber at a temperature of $10{ }^{\circ} \mathrm{C}$ for five days, and they were then transferred to a germinator with controlled temperature of $25^{\circ} \mathrm{C}$, where they remained for ten days. At the end of the test, the percentage of normal seedlings was calculated.

The electrical conductivity was determined using four subsamples with 50 seeds from each treatment weighted and soaked into $75 \mathrm{~mL}$ of distilled and deionized water at $25{ }^{\circ} \mathrm{C}$, for 24 hours. After this period, the electrical conductivity of the soaking solution was determined through a digital conductivity meter from the Gehaka brand, model CG 1800, and the results obtained on the readings $\left(\mathrm{mS} \mathrm{.} \mathrm{cm}^{-1}\right)$ from each replication were divided by the respective mass, obtaining the final result in $\mathrm{mS} . \mathrm{cm}^{-1} \cdot \mathrm{g}^{-1}$ (Vieira and Krzyzanowski, 1999).

The experiment was assembled on a design with $4 \mathrm{x}$
6 subdivided plots, with four drying air temperatures on the plots and six different storage times on the subplots, on a completely randomized design. In order to evaluate the latent effect of the drying temperatures, the data were subjected to regression analysis. The models were selected considering the magnitude of the determination coefficient $\left(\mathrm{R}^{2}\right)$, the regression significant, according to the $\mathrm{F}$ test, and the studied phenomenon.

\section{Results and Discussion}

Figure 1 shows the mean daily values for the temperature and relative humidity of the air of the storage environment of the peanut fruits during the 150 days of storage. Since the environmental conditions were not controlled, thermal and relative humidity variations were noticed. The mean temperature during the storage period was $25.8^{\circ} \mathrm{C}$, considering that the maximal temperature was $35^{\circ} \mathrm{C}$, and the minimal was $22{ }^{\circ} \mathrm{C}$. The mean relative humidity was $41 \%$, and the recorded maximal was $65 \%$, and the minimal was $21 \%$.

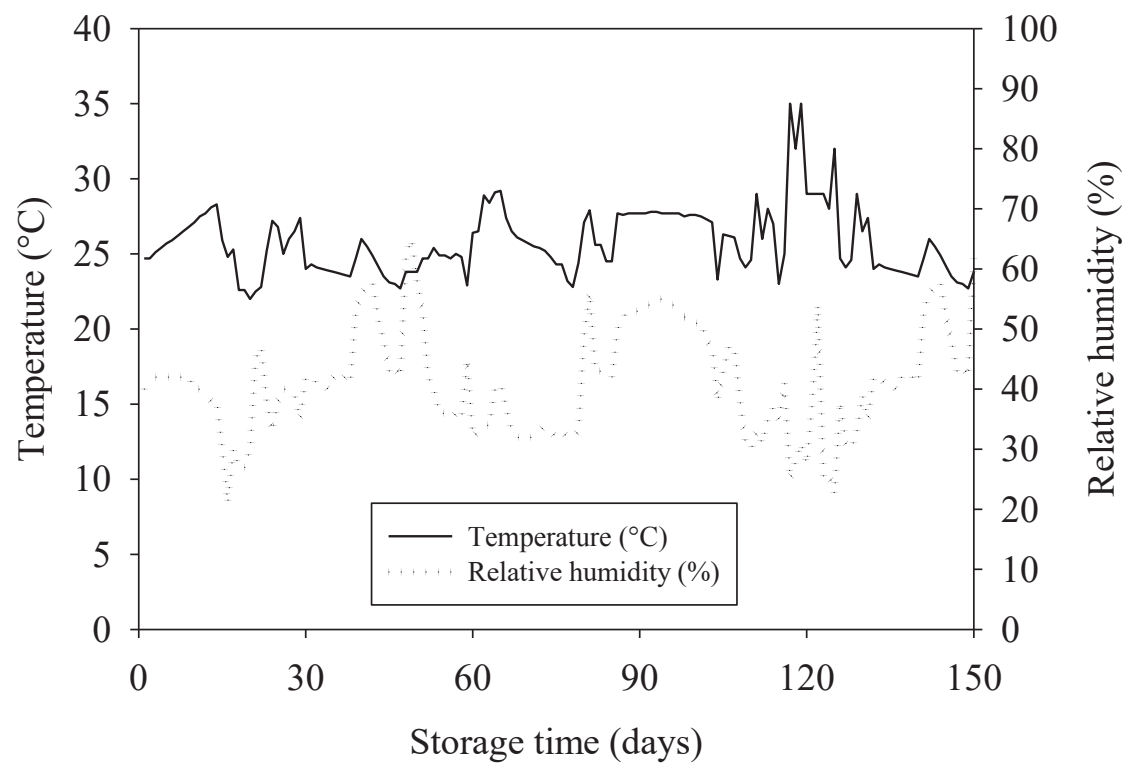

Figure 1. Daily means for the temperature and relative air humidity during the storage of the peanut fruits on an uncontrolled environment.

Table 1 shows that, due to the hygroscopicity both in relation to the fruits and the seeds, oscillations on the water contents of both occurred during storage, above all, due to the uncontrolled temperature and relative humidity conditions, which allowed the occurrence of phenomena such as sorption and desorption (Tiecker Junior et al., 2014). In addition, the lower balance water content observed for the seeds, in comparison to the fruits, probably occurred due to the high hydrophobic potential of the seeds with a high oil content.

Deliberali et al. (2010) and Bessa et al. (2015) also attributed the variation on the water content of the grains of Triticum aestivum and Crambe abyssinica, respectively, to the temperature and relative humidity variations when subjected to a conventional storage system. However, other factors in addition to the chemical composition of the grains and the environmental conditions are also highlighted by other authors 
as responsible for the variations on the water content of the product during storage, such as: the drying air temperature, the physical integrity and the sanitary condition of the seeds, in addition to genetic factors (Chen, 2000; Carneiro et al., 2005).

Table 1. Mean values of the water content ( $\%$ b.u.) of the peanut seeds (S) and fruits (F), according to the drying temperature and the storage time.

\begin{tabular}{ccccccccc}
\hline Storage & \multicolumn{8}{c}{ Drying temperature $\left({ }^{\circ} \mathrm{C}\right)$} \\
\cline { 2 - 9 } time & \multicolumn{2}{c}{40} & \multicolumn{3}{c}{50} & \multicolumn{2}{c}{60} \\
\cline { 2 - 9 } (days) & $\mathrm{S}$ & $\mathrm{F}$ & $\mathrm{S}$ & $\mathrm{F}$ & $\mathrm{S}$ & $\mathrm{F}$ & $\mathrm{S}$ & $\mathrm{F}$ \\
\hline 0 & 5.8 & 7.1 & 4.9 & 5.7 & 5.4 & 6.6 & 4.7 & 5.6 \\
30 & 4.9 & 5.8 & 4.7 & 5.3 & 4.8 & 5.5 & 4.6 & 5.3 \\
60 & 6.3 & 6.5 & 5.9 & 6.4 & 6.1 & 6.5 & 5.6 & 6.3 \\
90 & 4.9 & 5.9 & 4.8 & 6.0 & 4.9 & 5.7 & 4.6 & 5.4 \\
120 & 4.8 & 5.6 & 4.8 & 5.5 & 4.9 & 5.7 & 4.7 & 5.5 \\
150 & 4.7 & 5.6 & 4.7 & 5.3 & 4.8 & 5.6 & 4.5 & 5.3 \\
\hline
\end{tabular}

There was a significant effect between the drying temperatures and the storage time for the germination of seeds, and an immediate reduction on the percentage of normal seedlings was observed as the drying air temperature raised. This deleterious effect was potentiated on a linear manner as the storage progressed (Figure 2a). In addition, an increase could also be observed on the percentage of abnormal seedlings as both factors increased (Figure 2b), as well as a decrease on the percentage of dead seeds (Figure 2c).

Right after drying, the percentages of normal seedlings observed on the germination test for the temperatures of $40,50,60$ and $70{ }^{\circ} \mathrm{C}$ were $96,84,65$ and $10 \%$, respectively. However, due to the occurrence of the referred latent behavior, at the end of the 150 days of storage, the observed percentages for the same temperatures were 83, 59, 41 and $0 \%$ (Figure 2a). Therefore, in case the parameters established by the normative guideline number 45 suggested by Brasil (2013) was adopted, which establishes as the minimal limit for the commercialization of peanut seeds as $70 \%$ of normal seedlings upon the germination test, only the lot of seeds dried at $40{ }^{\circ} \mathrm{C}$ could be marketed after the 150 days of storage, since the lot dried at $50{ }^{\circ} \mathrm{C}$ did not meet this requirements approximately after 90 days, and the other lots immediately after drying.

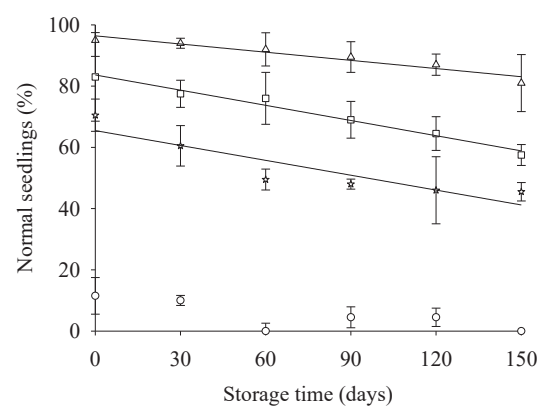

(a)

$\mathrm{N}_{40}{ }^{\circ} \mathrm{C}=96.4286-0.0890 \mathrm{TA}$

$\mathrm{N}_{50}{ }^{\circ} \mathrm{C}=83.6429-0.1652 \mathrm{TA}$

$\mathrm{N}_{60}{ }^{\circ} \mathrm{C}=65.4762-0.1619 \mathrm{TA}$

$\mathrm{N}_{70}{ }^{\circ} \mathrm{C}=10.0476-0.0662 \mathrm{TA}$

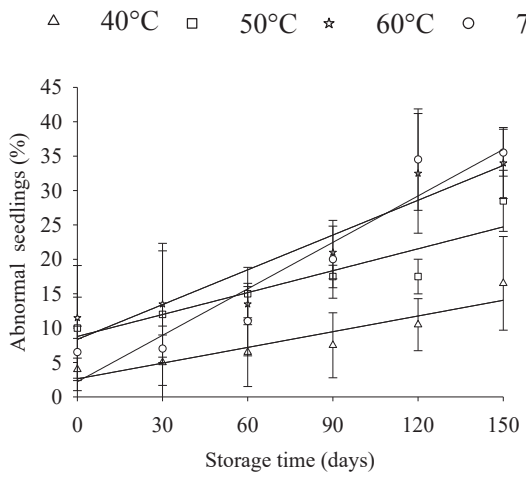

(b)

$\left(\mathrm{R}^{2}=0.9075\right) \quad \mathrm{A}_{40}{ }^{\circ} \mathrm{C}=2.6190+0.0762 \mathrm{TA}$

$\left(\mathrm{R}^{2}=0.9734\right) \quad \mathrm{A}_{50}{ }^{\circ} \mathrm{C}=8.7857+0.1062 \mathrm{TA}$

$\left(\mathrm{R}^{2}=0.7733\right) \quad \mathrm{A}_{60}{ }^{\circ} \mathrm{C}=8.3571+0.1686 \mathrm{TA}$

$\left(\mathrm{R}^{2}=0.4828\right) \quad \mathrm{A} 70{ }^{\circ} \mathrm{C}=2.1905+0.2252 \mathrm{TA}$

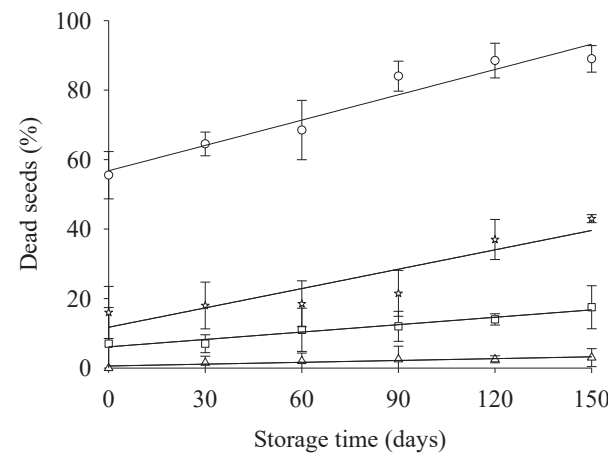

(c)
$\left(\mathrm{R}^{2}=0.8350\right) \quad \mathrm{D}_{40}{ }^{\circ} \mathrm{C}=0.5952+0.0176 \mathrm{TA} \quad\left(\mathrm{R}^{2}=0.8206\right)$

$\left(\mathrm{R}^{2}=0.8053\right) \quad \mathrm{D}_{50}{ }^{\circ} \mathrm{C}=6.0952+0.0710 \mathrm{TA}$

$\left(\mathrm{R}^{2}=0.8600\right) \quad \mathrm{D}_{60}{ }^{\circ} \mathrm{C}=11.7381+0.1857 \mathrm{TA}$

$\left(\mathrm{R}^{2}=0.8880\right) \quad \mathrm{D}_{70}{ }^{\circ} \mathrm{C}=56.7857+0.2429 \mathrm{TA}$
$\left(\mathrm{R}^{2}=0.9411\right)$

$\left(\mathrm{R}^{2}=0.7949\right)$

$\left(\mathrm{R}^{2}=0.9205\right)$

Figure 2. Results for the percentage of normal (a) and abnormal (b) seedlings and dead seeds (c) for the germination test of the peanut seeds, according to the drying temperature and the storage time.

In relation to the lot with seeds dried at $70{ }^{\circ} \mathrm{C}$, it could be observed that, although the low percentage of abnormal seedlings $(2 \%)$ does not portray the severity of the damages caused by the temperature immediately after drying, the number of dead seeds observed (57\%) and the potentiation of the latent deleterious effect evidenced by both variables, expressed by the increasing multiplicative coefficient, are an evidence of such behavior (Figures $2 \mathrm{~b}$ and $2 \mathrm{c}$ ).
A significant effect was observed regarding the interaction between the drying temperatures and the storage of seeds for the first count test. Furthermore, in addition to the promotion of normal seedlings as evidence of the vigor of the seeds submitted to drying and storage, the speed of the germination process, under adequate circumstances, could also be observed, since the test allows this verification, as reported by Nakagawa (1999) and Tillmann and Menezes (2012). Therefore, since the observed 
results decreased as the air temperature and the storage time increased, as well as right after drying (94, 76, 68 and 7\%) and at the end of the experiment $(63,42,30$ e $0 \%)$, it could be inferred that the germination speed was reduced (Figure 3).

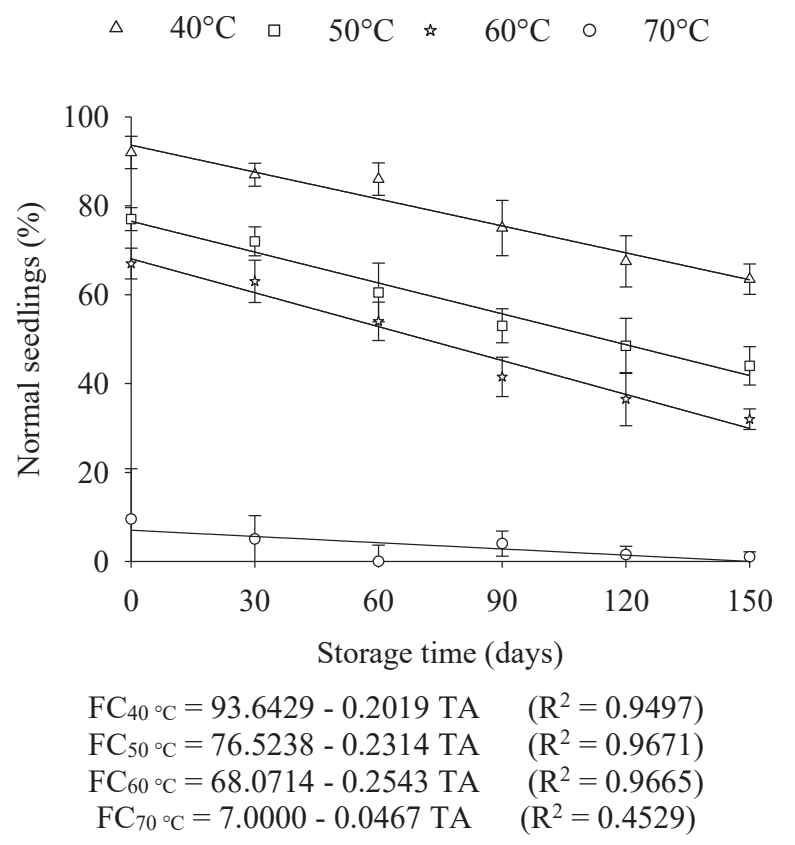

Figure 3. Results for the percentage of normal seedlings for the first count test with peanut seeds, according to the drying temperature and the storage time.

When evaluating the effect of different drying temperatures on the physiological quality of saccharine sorghum seeds, Ullmann et al. (2015) obtained similar results to the ones found here. The authors observed that, as the drying air temperature increased, both the germination percentage and the speed of the germination process, indirectly expressed by the first count, are reduced. As suggested by Afrakhteh et al. (2013), such fact is usually a result of the increase on the speed in which the water is removed from the product, which is stimulated by the increase on the drying air temperature; by creating a very high gradient different between the outer and the inner part of the product, it promotes the formation of tegumentary clefts and microcracks on cotyledons, negatively impacting the quality of the seed. In addition, situations such as these also increase the susceptibility of the material to latent damages, or also aggravate their deterioration, therefore, reducing the longevity of the product and its quality (Mbofung et al., 2013).

A significant effect of the interaction between the drying temperatures and storage was observed for the tetrazolium test, which also indicated the reduction on the physiological quality of the seeds, indicating the negative effects on the percentage of viable seeds (Figure 4). However, since the test uses the coloration of living tissues as its evaluation parameter, its sensitivity to differentiate the lots, despite being immediately clear, was more evident when the drying air temperature of $70{ }^{\circ} \mathrm{C}$ was used, considering that the lots dried at 40,50 and $60^{\circ} \mathrm{C}$ showed a more expressive difference on the coloration from 30 days of storage. As a consequence, therefore, it could be assumed that the damages promoted by the temperature of $70{ }^{\circ} \mathrm{C}$ were both of a physical and thermal nature, since the penetration of the tetrazolium salt was supposedly facilitated by the promotion of clefts on the cotyledons, as a result of the high water reduction rate, and also due to the lesions caused on the tissues, especially on the cellular membranes, resulting from the exposure to a high drying temperature for the culture.

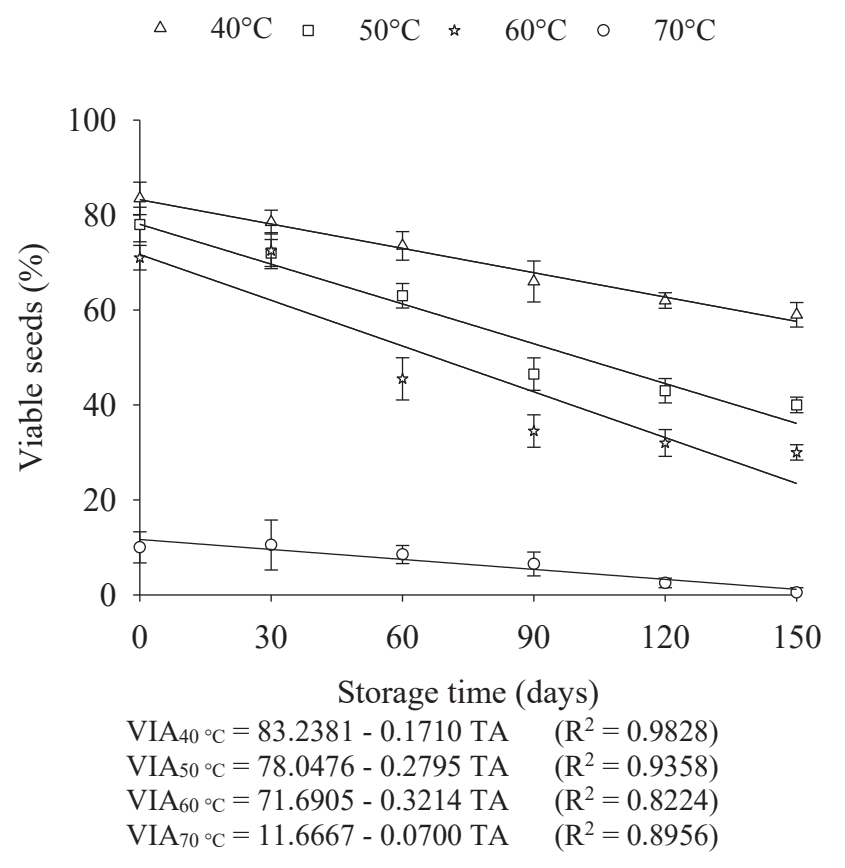

Figure 4. Results for the percentage of viable peanut seeds, according to the temperature of the drying air and the storage time.

On Table 2, it may be observed that the difference between the water content of the seeds subjected to drying temperatures of $40,50,60$ and $70{ }^{\circ} \mathrm{C}$, after the aging period, was within the limit of 4 percentage points on all evaluation times, therefore, conferring reliability to the test, as explained by Marcos-Filho (1999). 
Table 2. Mean values for the water content (\% b.u.) of peanut seeds, subjected to 48 hours of accelerated aging at $40^{\circ} \mathrm{C}$, according to the drying temperature and the storage time.

\begin{tabular}{ccccc}
\hline $\begin{array}{c}\text { Storage time } \\
\text { (days) }\end{array}$ & \multicolumn{4}{c}{ Drying temperatures $\left({ }^{\circ} \mathrm{C}\right)$} \\
\cline { 2 - 5 } & 40 & 50 & 60 & 70 \\
\hline 0 & 9.7 & 11.3 & 12.7 & 12.2 \\
30 & 13.9 & 10.9 & 13.9 & 12.1 \\
60 & 10.5 & 12.1 & 13.8 & 12.3 \\
90 & 10.5 & 13.7 & 12.7 & 15.5 \\
120 & 14.9 & 14.2 & 14.4 & 12.8 \\
150 & 14.7 & 14.9 & 14.2 & 14.4 \\
\hline
\end{tabular}

There was a significant effect of the drying temperatures and storage for the accelerated aging and cold tests that also indicated the reduction on the vigor of seeds as both factors increased, as well as the progressive increase of the susceptibility of the material to the adverse environmental conditions imposed by the tests, such as the high temperature and relative humidity (accelerated aging) and low temperature (cold test) (Figure 5).

Immediately after drying, the percentage of normal seedlings observed for the accelerated aging test, related to the drying temperatures of $40,50,60$ and $70{ }^{\circ} \mathrm{C}$, were 93,79 , 67 and $25 \%$, respectively. However, at the end of the 150 days of storage, the results observed for the same temperatures were 78, 54, 36 and $0 \%$ (Figure 5a), indicating the occurrence of deteriorative effects during storage. For the cold test with soil, the results observed for the same drying temperatures and evaluation times were $90,71,36$ and $7 \%$, respectively, and 58, 36, 14 and $0 \%$ (Figure 5b). However, since the results observed for the cold test were lower in relation to the values obtained by the aging test, a greater susceptibility of the seeds to cold possibly occurred, due to the imposed treatments, than under the high temperature and relative humidity conditions.

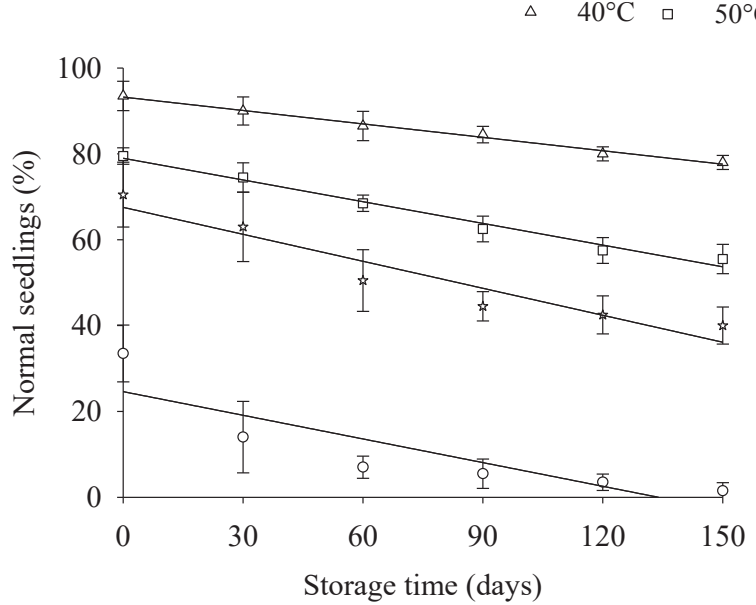

(a)

$\begin{array}{ll}\mathrm{AA}_{40}{ }^{\circ} \mathrm{C}=93.2381-0.1043 \mathrm{TA} & \left(\mathrm{R}^{2}=0.9897\right) \\ \mathrm{AA}_{50}{ }^{\circ} \mathrm{C}=78.9762-0.1686 \mathrm{TA} & \left(\mathrm{R}^{2}=0.9800\right) \\ \mathrm{AA}_{60}{ }^{\circ} \mathrm{C}=67.5476-0.2095 \mathrm{TA} & \left(\mathrm{R}^{2}=0.8935\right) \\ \mathrm{AA}_{70}{ }^{\circ} \mathrm{C}=24.6190-0.1838 \mathrm{TA} & \left(\mathrm{R}^{2}=0.6897\right)\end{array}$

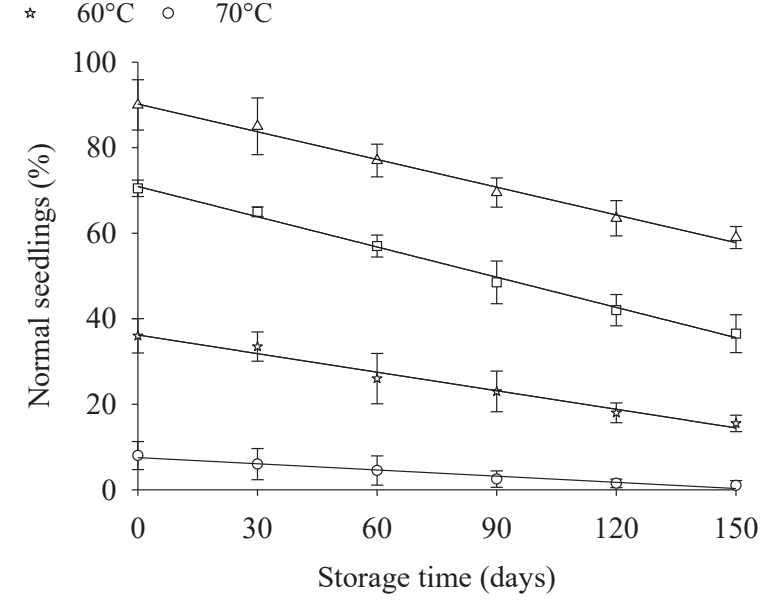

(b)

$$
\begin{array}{ll}
\mathrm{CT}_{40}{ }^{\circ} \mathrm{C}=90.2143-0.2162 \mathrm{TA} & (\mathrm{R} 2=0.9909) \\
\mathrm{CT}_{50}{ }^{\circ} \mathrm{C}=70.9286-0.2357 \mathrm{TA} & (\mathrm{R} 2=0.9939) \\
\mathrm{CT}_{60}{ }^{\circ} \mathrm{C}=36.1905-0.1448 \mathrm{TA} & (\mathrm{R} 2=0.9749) \\
\mathrm{CT}_{70}{ }^{\circ} \mathrm{C}=7.5238-0.0481 \mathrm{TA} & (\mathrm{R} 2=0.9577)
\end{array}
$$

Figure 5. Results for the percentage of normal seedlings for the accelerated aging test (a) and for the cold test with soil (b), according to the drying temperature and the storage time.

When evaluating the physiological quality of rice seeds submitted to different drying air temperatures through the accelerated aging and cold tests, Menezes et al. (2012a) also observed that, as the air temperature increases, the vigor of the seeds is reduced, since the seed gets more susceptible to adverse environmental conditions, since its integrity is compromised due to the deleterious effects of drying.

A significant effect of the drying temperatures and storage was observed for the electrical conductivity test, and it was observed that the increase on the drying air temperature was determinant to reduce the physiological quality of the seeds, as well as to aggravate the situation as storage progressed, since the results obtained by the test immediately after drying showed an increasing nature and, as the time progressed, they behave in a positive and progressive linear manner for all drying temperatures (Figure 6). 


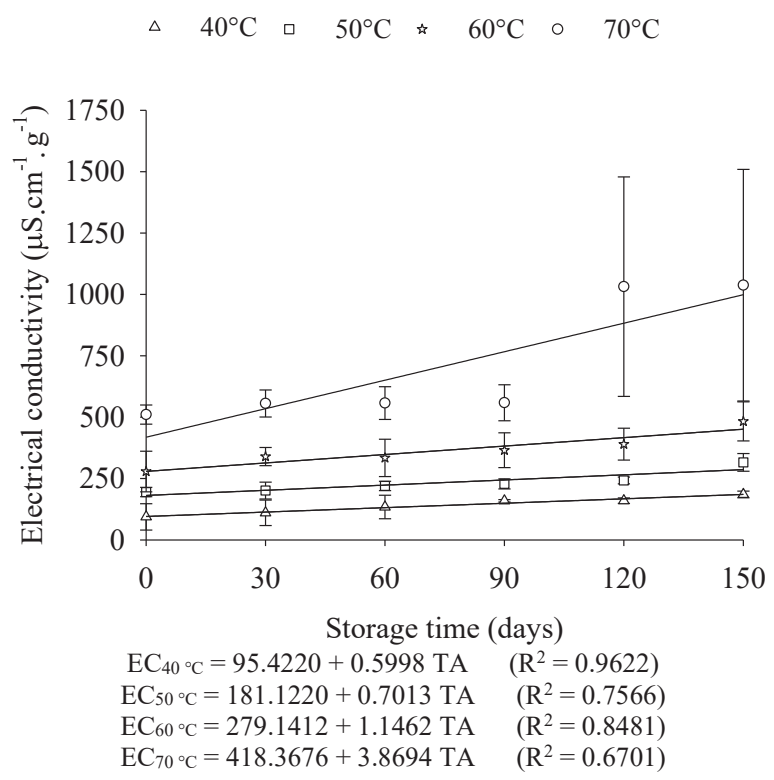

Figure 6. Results of the electrical conductivity of the soaking solution of peanut seeds, according to the drying temperature and the storage time.

These results indicate that the loss of integrity of the components of the membrane was caused by drying at temperatures above $40^{\circ} \mathrm{C}$, associated to the prolonged storage, since, according to Marcos-Filho (2015), the electrical conductivity test expresses the degree of disorganization of the cell membranes, since the higher their integrity, the greater will be their capacity not to allow leaching and ions from its interior to the soaking solution. However, the integrity may usually be compromised by some factors, such as by the drying air temperature and the storage time, as observed for bean seeds (Faroni et al., 2006), jatropha seeds (Ullmann et al., 2010), adzuki bean seeds (Resende et al., 2012; Almeida et al., 2013), soy seeds (Smaniotto et al., 2014) and saccharine sorghum seeds (Ullmann et al., 2015), whose results related to the electrical conductivity also showed damages occurred on the cellular membranes of the seeds submitted to temperatures above $40{ }^{\circ} \mathrm{C}$ and storage periods of over 100 days.

\section{Conclusions}

The increase on the drying air temperature affects the physiological potential of the peanut seeds, and this effect is potentiated according to the storage time.

The drying air temperature of $40{ }^{\circ} \mathrm{C}$ favors the maintenance of the germination capacity of the seeds during the storage period of 150 days.

\section{Acknowledgments}

The financial support provided by the Coordenação de Aperfeiçoamento de Pessoal de Nível Superior - Capes, and by the Fundação de Apoio ao Desenvolvimento do Ensino, Ciência e Tecnologia do Estado do Mato Grosso do Sul - Fundect.

\section{References}

AFONSO JÚNIOR, P.C.; CORRÊA, P.C. Efeitos imediato e latente da secagem de sementes de feijão colhidas com diferentes níveis de umidade. Ciência e Agrotecnologia, v.24, p.33-40, 2000. http://www.editora.ufla.br/ index.php/revistas/ciencia-e-agrotecnologia/artigos-publicados/10-volumesrevista/65-edicaoespeciale

AFRAKHTEH, S.; FRAHMANDFAR, E.; HAMIDI, A., RAMANDI, H.D. Evaluation of growth characteristics and seedling vigor in two cultivars of soybean dried under different temperature and fluidized bed dryer. International Journal of Agriculture and Crop Sciences, v.5, n.21, p.25372544, 2013. http://ijagcs.com/wp-content/uploads/2013/09/2537-2544.pdf

ALMEIDA, D.P.; RESENDE, O.; MENDES, U.C.; COSTA, L.M.; CORRÊA, P.C.; ROCHA, A.C. Influência da secagem na qualidade fisiológica do feijão adzuki. Agrária - Revista Brasileira de Ciências Agrárias, v.8, n.2, p.311-315, 2013. http://agraria.pro.br/sistema/index.php?journal=agraria\&page=article\&op=view\&path $\% 5 \mathrm{~B} \% 5 \mathrm{D}=$ agraria_v8i2a $2164 \&$ path $\% 5 \mathrm{~B} \% 5 \mathrm{D}=1369$

ARAUJO, W.D.; GONELI, A.L.D.; SOUZA, C.M.A.; GOLÇALVES, A.A.; VILHASANTI, H.C.B. Propriedades físicas dos grãos de amendoim durante a secagem. Revista Brasileira de Engenharia Agrícola e Ambiental, v.18, n.3, p.279-286, 2014. http://www.agriambi.com.br/revista/v18n03/v18n03a06.pdf

BARBOSA, R.M.; VIEIRA, B.G.T.L.; MARTINS, C.C.; VIEIRA, R.D. Qualidade fisiológica e sanitária de sementes de amendoim durante o processo de produção. Pesquisa Agropecuária Brasileira, v.49, n.12, p.977-985, 2014. http://seer.sct.embrapa.br/index.php/pab/article/view/19217/12839

BARROS, A.S.R.; DIAS, M.C.L.L.; CICERO, S.M.; KRZYZANOWSKI, F.C. Testes de frio. In: KRZYZANOWSKI, F.C.; VIEIRA, R.D.; FRANÇANETO, J.B. (Eds.). Vigor de sementes: conceitos e testes. Londrina: ABRATES, 1999. p.5-1 a 5-15.

BESSA, J.F.V.; DONADON, J.R.; RESENDE, O.; ALVES, R.M.V.; SALES, J.F.; COSTA, L.M. Armazenamento do crambe em diferentes embalagens e ambientes: parte I - qualidade fisiológica. Revista Brasileira de Engenharia Agricola e Ambiental, v.19, n.3, p.224-230, 2015. http://www.agriambi.com. br/revista/v19n03/v19n03a05.pdf

BRASIL. Instrução Normativa, $\mathrm{n}^{\circ} .45$, de 17 de setembro de 2013. Padrões de Identidade e Qualidade para a produção e a comercialização de sementes. Seção 1. Ministério da Agricultura, Pecuária e Abastecimento. Diário Oficial da União de 20/09/2013. Brasília. http://apasem.com.br/site/index.php/ instrucao-normativa-no-45/

BRASIL. Ministério da Agricultura, Pecuária e Abastecimento. Regras para análise de sementes. Ministério da Agricultura, Pecuária e Abastecimento. Secretaria de Defesa Agropecuária. Brasília: MAPA/ACS, 2009. 395p. http:// www.agricultura.gov.br/arq_editor/file/2946_regras_analise_sementes.pdf

CARNEIRO, L.M.T.A.; BIAGI, J.D.; FREITAS, J.G.; CARNEIRO, M.C.; FELÍCIO, J.C. Diferentes épocas de colheita, secagem e armazenamento na qualidade de grãos de trigo comum e duro. Bragantia, v.64, n.1, p.127-137, 2005. http://www.scielo.br/pdf/brag/v64n1/23860.pdf 
CHEN, C. Factors which effect equilibrium relative humidity of agricultural products. Transactions of the American Society of Agricultural Engineers, v.43, n.3, p.673-683, 2000. http://elibrary. asabe.org/abstract. asp aid $=2749 \& \mathrm{t}=2 \&$ redir $=$ aid $=2749 \&$ confalias $=\&$ redir $=[$ volume $=43 \&$ is sue $=3 \& \operatorname{conf}=$ t $\&$ orgcon $\mathrm{f}=\mathrm{t} 2000] \&$ redirType $=$ toc journals.asp\&redirType $=$ toc journals.asp

DELIBERALI, J.; OLIVEIRA, M.; DURIGON, A.; DIAS, A.R.G.; GUTKOSKI, L.C.; ELIAS, M.C. Efeitos de processo de secagem e tempo de armazenamento na qualidade tecnológica de trigo. Ciência e Agrotecnologia, v.34, n.5, p.1285-1292, 2010. http://www.scielo.br/pdf/cagro/v34n5/29.pdf

FARIA, R.Q.; TEIXEIRA, I.R.; CUNHA, D.A.; HONORATO, J.M.; DEVILLA, A. Qualidade fisiológica de sementes de crambe submetidas à secagem. Revista Ciência Agronômica, v.45, n.3, p.453-460, 2014. http:// www.ccarevista.ufc.br/seer/index.php/ccarevista/article/view/2306/971

FARONI, L.R.A.; CORDEIRO, I.C.; ALENCAR, E.R.; ROZADO, A.F.; ALVES, W.M. Influência do conteúdo de umidade de colheita e temperatura de secagem na qualidade do feijão. Revista Brasileira de Engenharia Agricola e Ambiental, v.10, n.1, p.148-154, 2006. http://www.scielo.br/pdf/ rbeaa/v10n1/v10n1a22.pdf

FERNANDES, E.M.; ROSOLEM, C.A. Produtividade de amendoim em função da calagem e do método de secagem. Pesquisa Agropecuária Brasileira, v.34, n.1, p.11-20, 1999. http://seer.sct.embrapa.br/index.php/pab/ article/view/5142/2334

KRZYZANOWSKI, F.C.; WEST, S.H.; FRANÇA-NETO, J.B. Drying peanut seed using air ambient temperature at low relative humidity. Revista Brasileira de Sementes, v.28, n.3, p. 1-5, 2006. http://www.abrates.org.br/ artigos-publicados

MARCOS-FILHO, J. Fisiologia de sementes de plantas cultivadas. 2 ed. Londrina, PR: ABRATES, 2015. 660p.

MARCOS-FILHO, J. Teste de envelhecimento acelerado. In: KRZYZANOWSKI, F.C.; VIEIRA, R.D.; FRANÇA-NETO, J.B. (Eds.). Vigor de sementes: conceitos e testes. Londrina-PR: ABRATES, 1999. p.3-1 a 3-24.

MBOFUNG, G.C.Y.; GOGGI, A.S.; LEANDRO, L.F.S.; MULLEN, R.E. Effects of storage temperature and relative humidity on viability and vigor of treated soybean seeds. Crop Science, v.53, n.3, p.1086-1095, 2013. https:// dl.sciencesocieties.org/publications/cs/articles/53/3/1086

MENEZES, N.L.; PASQUALLI, L.L.; BARBIERI, A.P.P.; VIDAL, M.D.; CONCEIÇÃO, G.M. Temperaturas de secagem na integridade física, qualidade fisiológica e composição química de sementes de arroz. Pesquisa Agropecuária Tropical, v.42, n.4, p.430-436, 2012a. https:// www.revistas.ufg.br/index.php?journal=pat\&page=article\&op=view\&path $\% 5 \mathrm{~B} \% 5 \mathrm{D}=18457 \&$ path $\% 5 \mathrm{~B} \% 5 \mathrm{D}=12715$

MENEZES, N.L.; CICERO, S.M.; VILLELA, F.A.; BORTOLOTTO, R.P. Using X-rays to evaluate fissures in rice seeds dried artificially. Revista Brasileira de Sementes, v.34, n.1, p.70-77, 2012b. http://www.scielo.br/pdf/ $\mathrm{rbs} / \mathrm{v} 34 \mathrm{n} 1 / \mathrm{a} 09 \mathrm{v} 34 \mathrm{n} 1 . \mathrm{pdf}$

MOORE, R. P. Handbook on tetrazolium testing. International Seed Testing Association - ISTA, 1985. 99p.

MUTEGI, C.K.; WAGACHA, J.M.; CHRISTIE, M.E.; KIMANI, J.; KARANJA, L. Effect of storage conditions on quality and aflatoxin contamination of peanuts (Arachis hypogaea L.). International Journal of AgriScience, v.3, n.10, p.746-758, 2013. http://oar.icrisat.org/7288/1/ IntlJAgriSci_3_10_746_758_2013.pdf
NAKAGAWA, J. Teste de vigor baseados no desempenho de plântulas. In: KRZYZANOWSKI, F.C.; VIEIRA, R.D.; FRANÇA-NETO, J.B. (Eds.). Vigor de sementes: conceitos e testes. Londrina: ABRATES, 1999. p.2-1 a 2-24.

NAKAGAWA, J.; ROSOLEM, C.A. O Amendoim: Tecnologia de Produção. Botucatu: FEPAF, 2011, 325p.

OLIVA, A.C.E.; BIAGGIONI, M.A.M.; CAVARIANI, C. Efeito imediato do método de secagem na qualidade de sementes de crambe. Revista Energia na Agricultura, v.27, n.3, p.16-30, 2012. http://revistas.fca.unesp.br/index.php/ energia/article/view/645/303

PESKE, S.T.; VILLELA, F.A.; MENEGHELlO, G.E. (Eds). Sementes: fundamentos científicos e tecnológicos. Pelotas: Editora Universitária da UFPel, 3.ed., 2012. 573p.

RESENDE, O.; ALMEIDA, D.P.; COSTA, L.M.; MENDES, U.C.; SALES, J.F. Adzuki beans (Vigna angularis) seed quality under several drying conditions. Ciência e Tecnologia de Alimentos, v.32, n.1, p.151-155, 2012. http://www.scielo.br/pdf/cta/v32n1/aop_cta_5007.pdf

SANTOS, R.C.; FREIRE, R.M.M.; LIMA, L.M.; AGONEL, G.F.; COSTA, B.J. Produtividade de grãos e óleo de genótipos de amendoim para o mercado oleoquímico. Revista Ciência Agronômica, v.43, n.1, p.72-77, 2012. http:// www.ccarevista.ufc.br/seer/index.php/ccarevista/article/view/1564/671 v

SMANIOTTO, T.A.S.; RESENDE, O.; MARÇAL, K.A.F.; OLIVEIRA, D.E.C.; SIMON, G.A. Qualidade fisiológica das sementes de soja armazenadas em diferentes condições. Revista Brasileira de Engenharia Agrícola e Ambiental, v.18, n.4, p.446-453, 2014. http://www.agriambi.com. br/revista/v18n04/v18n04a13.pdf

TIECKER JUNIOR, A.; GUIMARÃES, L.E.; FERRARI FILHO, E.; CASTRO, B.; DEL PONTE, E.M.; DIONELLO, R.G. Qualidade físicoquímica de grãos de milho armazenados com diferentes umidades em ambientes hermético e não hermético. Revista Brasileira de Milho e Sorgo, v.13, n.2, p.174-186, 2014. http://rbms.cnpms.embrapa.br/index.php/ojs/ article/view/484/pdf_93

TILLMANN, M.A.A.; MENEZES, N.L. Análise de sementes. In: PESKE, S.T.; VILLELA, F.A.; MENEGHELLO, G.E. (Eds.). Sementes: fundamentos científicos e tecnológicos. Pelotas: Editora Universitária da UFPel, 3.ed., 2012. p.161-272.

ULLMANN, R.; RESENDE, O.; SALES, J.F.; CHAVES, T.H. Qualidade das sementes de pinhão manso submetidas à secagem artificial. Revista Ciência Agronômica, v.41, n.3, p. 442-447, 2010. http://www.ccarevista.ufc.br/seer/ index.php/ccarevista/article/view/911/463

ULLMANN, R.; RESENDE, O.; CHAVES, T.H.; OLIVEIRA, D.E.C.; COSTA, L.M. Qualidade fisiológica das sementes de sorgo sacarino submetidas à secagem em diferentes condições de ar. Revista Brasileira de Engenharia Agrícola e Ambiental, v.19, n.1, p.64-69, 2015. http://www. agriambi.com.br/revista/v19n01/v19n01a11.pdf

VASCONCELOS, F.M.T.; VASCONCELOS, R.A.; LUZ, L.N.; CABRAL, N.T.; OLIVEIRA JÚNIOR, J.O.L.; SANTIAGO, A.D.; SGRILLO, E.; FARIAS, F.J.C.; MELO FILHO, P.A.; SANTOS, R.C. Adaptabilidade e estabilidade de genótipos eretos de amendoim cultivados nas regiões Nordeste e Centro-Oeste. Ciência Rural, v.45, n.8, p.1375-1380, 2015. http:// www.scielo.br/pdf/cr/v45n8/0103-8478-cr-45-08-01375.pdf

VIEIRA, R.D.; KRZYZANOWSKI, F.C. Teste de condutividade elétrica. In: KRZYZANOWSKI, F.C.; VIEIRA, R.D.; FRANÇA-NETO, J.B. (Eds.). Vigor de sementes: conceitos e testes. Londrina-PR: ABRATES, 1999. p.4-1 a 4-26. 